\title{
Calf performance when fed with cheese whey associated with discarded powdered milk
}

\section{Desempenho de bezerros aleitados com soro de queijo associado ao leite em pó descartado}

\author{
Andrezza Kyarelle Bezerra de Moura ${ }^{1 *}$; Renata Nayhara de Lima ${ }^{2}$; Kátia Tatiana \\ de Lima Lopes 3 ; João Artur de Lima Neto 3 ; Vítor Lucas de Lima Melo 3 ; \\ Patrícia de Oliveira Lima ${ }^{4}$; Josemir de Souza Goncalves ${ }^{4}$
}

\begin{abstract}
The objective of this study was to evaluate the performance of calves (Holstein $\times$ No Defined Breed Standard) fed powdered cheese whey associated with discarded powdered milk up to 60 days of age. Forty calves (35 kg initial average weight) were used, distributed in a completely randomized design with four treatments and ten repetitions per treatment: whole milk (control), 100\% milk powder, $80 \%$ milk powder $+20 \%$ cheese whey powder, $60 \%$ milk powder $+40 \%$ cheese whey powder. Consumption, performance, and economic analysis were evaluated. Data were analyzed for variance and comparison of orthogonal contrasts $(\mathrm{P}<0.05)$. No significant differences were observed between the treatments tested regarding the evaluated variables. The animals from all treatments had a final average weight of $50.28 \mathrm{~kg}$ as the result of an average weight gain of $0.255 \pm 0.03 \mathrm{~kg} /$ day and a total dry matter intake of $34.28 \pm 1.47 \mathrm{~kg} /$ day per calf. The examined diets offered the lowest cost compared to the control treatment, generating an average additional profit of $113.19 \mathrm{R} \$$ animal. Diets containing whey cheese powder are the most economically advantageous options, as replacing $100 \%$ of milk with these byproducts did not impair animal performance. The use of discarded industrial milk powder combined with whey powder in a ratio of up to 80:20 is a viable option for feeding male calves in dairy farms. Key words: Economic evaluation. Crossbred calves. Consumption of dry matter. Weight development. Substitute.
\end{abstract}

\section{Resumo}

O objetivo desse trabalho foi avaliar o desempenho de bezerros (Holandês x Sem Padrão Racial Definido) aleitados com soro de queijo em pó associado ao leite em pó descartado até os 60 dias. Utilizou-se 40 bezerros (com peso médio inicial de $35 \mathrm{~kg}$ ), distribuído em delineamento inteiramente casualizado com quatro tratamentos: leite integral (Controle); $100 \%$ leite em pó; $80 \%$ leite em pó $+20 \%$ de soro de queijo em pó; $60 \%$ leite em pó $+40 \%$ de soro de queijo em pó e dez repetições. Foram avaliados o consumo, desempenho e análise econômica. Os dados foram submetidos à análise de variância e comparação dos contrastes ortogonais $(\mathrm{P}<0,05)$. Não foram observadas diferenças significativas entre os tratamentos

\footnotetext{
${ }_{1}$ Prof $f^{a}$ M.e, Instituto Federal de Educação, Ciência e Tecnologia do Pará, IFPA, Breves, PA, Brasil. E-mail: andrezza_kyarelle@ hotmail.com

$2 \operatorname{Prof}^{a}$ Dr $^{\mathrm{a}}$, Instituto Federal de Educação, Ciência e Tecnologia do Rio Grande do Norte, IFRN, Ipanguaçu, RN, Brasil. E-mail: renatalima_16@msn.com.br

3 Discentes, Universidade Federal Rural do Semi-Árido, UFERSA, Mossoró, RN, Brasil. E-mail: ktatylima@yahoo.com; joaoartur@gmail.com; vitor@gmail.com

4 Profs. Drs., UFERSA, Mossoró, RN, Brasil. E-mail: pattlima@ufersa.edu.br; josemir@ufersa.edu.br

* Author for correspondence
} 
testados sob as variáveis avaliadas. Os animais de todos os tratamentos apresentaram de peso médio final de 50,28 $\mathrm{kg}$ como um ganho de peso médio de $0,325 \pm 0,03 \mathrm{~kg} /$ dia e um consumo de matéria seca total de $34,28 \pm 1,47 \mathrm{~kg} /$ bezerro $\mathrm{x}$ dia. As dietas testadas apresentaram o menor custo em comparação ao tratamento controle, resultando num lucro adicional médio de 113,19 R \$/animal. As dietas contendo soro de queijo em pó são as opções mais vantajosas economicamente, já que a substituição de $100 \%$ do leite por esses subprodutos não prejudicou o desempenho dos animais. A utilização de leite em pó descartado nas indústrias associado ao soro de queijo em pó numa proporção de até 80:20, apresenta-se como uma opção viável para a alimentação de bezerros machos provenientes de propriedades leiteiras. Palavras-chave: Avaliação econômica. Bezerros mestiços. Consumo de matéria seca. Desenvolvimento ponderal. Sucedâneo.

\section{Introduction}

The search for new technologies is of paramount importance for proper management, where costs and benefits must be taken into account (SOBERON et al., 2012). Early weaning or the adoption of a substitute diet can reduce the final cost of a replacement heifer during the calf suckling period; as the calf reaches 60 days old, its consumption can reach 240 total liters of milk (assuming the consumption of $4 \mathrm{~L}$ of milk per day). Calf milk replacers are lower in cost than whole milk and offer the possibility of increasing the amount of milk available to be marketed by the producer (NRC, 2001).

Cheese whey is among the available dairy substitutes of animal origin. It is considered a byproduct of the dairy industry and it is derived from the cheese manufacturing process. According to Carvalho et al. (2013), whey is characterized as a greenish-yellow liquid effluent, free of casein and fat, obtained after the precipitation of casein. This processing method leads to the formation of two types of whey according to the cheese manufacturing method: acid whey $(\mathrm{pH}<5)$ obtained after fermentation or addition of organic or mineral acids, or sweet whey ( $\mathrm{pH} 6$-7), obtained by the addition of proteolytic enzymes such as bed chymosin during the manufacture of the dairy product. Cheese whey has a high organic load due to the presence of milk nutrient residues (such as lactose, proteins, lipids and vitamins). These elements make whey a potential resource for obtaining various valueadded products as well as animal feed (YADAV et al., 2015). Owing to this considerable organic load, untreated whey disposal is an important source of environmental pollution, and owing to the large volumes generated, it is generally associated with a substantial cost, underlining the importance of proper disposal or reuse of this by-product (LIMA et al., 2017).

Thanks to its high nutritional value, liquid cheese whey can be reused within the dairy chain as animal feed (PALMIERI et al., 2017). However, despite its excellent biological value, Lima et al. (2011) point out that total replacement of milk with whey is impossible because, although it is a dairy derivative, cheese whey has a specific composition that is significantly less nutritious when compared to the constitution of whole milk. A complete substitution can lead to a nutrient deficiency in nursing calves which negatively impacts their development.

It is also important to highlight that, in general, whey can be used to feed cattle without causing digestive disturbance at inclusion levels of up to $44 \%$ of dry matter, since liquid whey ferments easily. It owes this easy fermentation to its rich carbohydrate makeup and a particularly high lactose level. This results in an increase in the amount of lactic acid ingested by animals, contributing to a decrease in the $\mathrm{pH}$ of the rumen. This causes rumen lactic acidosis, and unbalances the normal rumen microbiota (GAVA et al., 2018). Therefore, associating with another low-lactose food would be a promising alternative (LIMA et al., 2012).

Several studies have been conducted to test the association of cheese whey at different levels with fresh milk and colostrum. In this study, we chose 
to associate cheese whey with industrial waste milk powder, which is one of the products that possesses similar nutritional characteristics to milk, at a good availability and low cost. Thus, the objective of this study was to evaluate the performance of crossbred calves suckled with whey associated with milk powder until 60 days of age.

\section{Material and Methods}

\section{Animals and diets}

The experiment was carried out at Flor da Serra farm located in Limoeiro do Norte/CE. Forty male crossbred Holstein $\times$ SPRD calves (with no defined breed standard) with initial average weights of 35 $\mathrm{kg}$ were used. The animals were distributed in a completely randomized design with four treatments: whole milk (Control); 100\% milk powder; $80 \%$ milk powder $+20 \%$ cheese whey powder; $60 \%$ milk powder $+40 \%$ cheese whey powder with ten repetitions. Both milk powder and cheese whey were reconstituted using clean, good quality water in a $1: 9$ ratio.

The animals arrived at the facility $24 \mathrm{~h}$ after birth to allow free consumption of colostrum directly from the mother until they reached three days old. They were then identified and housed in a fencedin, shaded area and divided so that each animal occupied a surface of $5.0 \mathrm{~m}^{2}$, limited by currents, with a sandy floor. The enclosures were equipped with individual buckets for water, concentrate and Tifton (Cynodon spp.) hay.

After the colostrum phase, the animals received whole milk, according to the management protocols already in place on the property. The control animals continued to consume only whole milk, while the others underwent adaptation, which lasted 10 days, to reduce any adverse impact of diet change on the animals' digestive tracts. The experimental period lasted 60 days and during this period all groups were fed $4 \mathrm{~L}$ of liquid diet split into two daily meals.

\section{Developmental assessment}

During the experimental period, calf growth was evaluated by weekly weighing always conducted in the morning before the liquid diet was provided. At the same time, body measurements were taken with a tape measure and a specific ruler for animal measurements. The following measurements were obtained: withers height - corresponding to the distance from withers to the ground surface, croup height - corresponding to the distance from the sacrum bone to the ground surface, thoracic perimeter - immediately caudal perimeter of the scapula passing through the sternum and spinal processes of the thoracic vertebrae, and body length - a straight line between the scapula-humeral joint and the lateral hip ileal tuberosity.

\section{Consumption rating}

Dry matter (DM) intake was evaluated by daily measurements of hay and concentrate intake administered through the offer/surplus method. Daily food portions were adjusted to a $10 \%$ surplus of the previous day's intake. Portions of the diets were removed daily to constitute a weekly composite sample for further analysis. Consumption variables were evaluated by determining concentrate intake ( $\mathrm{kg} /$ day), hay intake $(\mathrm{kg} /$ day) and total dietary dry matter ( $\mathrm{kg} /$ day), taking into consideration the dry matter of the solid and liquid diets, and the feed conversion of ingested dry matter (CAMS).

\section{Laboratory analysis of solid food composition}

The composition of solid foods was determined according to the methodology of Silva and Queiroz (2009), carried out at the Animal Nutrition Laboratory of the Federal Rural University of Semiarid, to determine dry matter (MS), mineral matter $(\mathrm{MM})$, crude protein $(\mathrm{CP})$, ethereal extract (EE), neutral detergent insoluble fiber (NDF), and acid detergent insoluble fiber (ADF) (Table 1). 
Table 1. Chemical composition of Tifton 85 grass hay and concentrate supplied to calves.

\begin{tabular}{lcc}
\hline \multicolumn{1}{c}{ Composition } & Concentrated & Hay \\
& - & 93,92 \\
Dry matter & 8,64 & 95,38 \\
Mineral matter & 18,54 & 7,91 \\
Crude protein & 4,98 & 7,94 \\
Ethereal extract & 13,73 & 1,58 \\
Neutral detergent fiber & 9,20 & 72,18 \\
Acid detergent fiber & & 36,89 \\
\hline
\end{tabular}

\section{Economic analysis}

For the economic analysis the costs associated with feeding and revenue from the possible commercialization of the carcasses of the animals were calculated. The economic analysis examined the costs associated with the tested diets in relation to the control treatment (whole milk). According to Lima et al. (2012), the following cost and revenue indicators were calculated for each diet: total revenue, carcass kilogram price multiplied by carcass yield (R\$/animal), additional revenue, difference between the total revenue obtained in each treatment and the total revenue obtained in the control treatment (R\$/animal), total cost of food in each treatment ( $\mathrm{R} \$$ animal), additional cost with food, difference between the total cost of food obtained in each treatment and the total cost verified in the control treatment, as well as additional profit, difference between the amount of the increase in additional revenue and the amount of the increase in food expense ( $\mathrm{R} \$$ /animal). The values attributed to the components of the diets were related to the current prices in the region of Limoeiro do Norte/ CE.

\section{Statistical analysis}

Data were subjected to analysis of variance and comparison through the following orthogonal contrasts: A - Whole milk vs. other treatments, B Linear effect of inclusion of cheese whey powder and C - Quadratic effect of inclusion of cheese whey in powder. The statistical model adopted was: $Y i j=$ $\mu+\mathrm{Ti}+$ Eij, using the computer program R 2.15.0 (2012) with a significance level of 5\% probability.

\section{Results and Discussion}

There was no significant effect $(\mathrm{P}>0.05)$ found in the evaluated contrasts regarding solid diet dry matter intake (concentrate and hay), total dry matter intake and feed conversion (Table 2). Throughout the experimental period associated with the liquid diet, the animals received concentrate and hay, contributing positively to the transition from the pre-ruminant stage to the functional ruminant stage. 
Table 2. Averages for total dry matter intake (ADMT kg /calf /day), concentrate dry matter intake (ADMC kg/calf / day), hay dry matter consumption (ADMH kg /calf/day)) and feed conversion (FC) of calves receiving milk powder and whey cheese in the liquid diet.

\begin{tabular}{|c|c|c|c|c|c|c|c|c|}
\hline \multirow{2}{*}{ Variables } & \multicolumn{4}{|c|}{ Treatments } & \multirow{2}{*}{ SEM } & \multicolumn{3}{|c|}{ P value of contrasts } \\
\hline & WM & MPW0 & MPW20 & MPW40 & & A & B & $\mathrm{C}$ \\
\hline ADMC & 0,302 & 0,346 & 0,323 & 0,315 & 0,025 & 0,730 & 0,755 & 0,926 \\
\hline ADMH & 0,080 & 0,088 & 0,080 & 0,081 & 0,005 & 0,837 & 0,666 & 0,759 \\
\hline ADMT & 36,25 & 34,48 & 33,89 & 34,36 & 1,47 & 0,558 & 0,979 & 0,888 \\
\hline $\mathrm{FC}$ & 1,46 & 1,46 & 1,58 & 1,45 & 0,05 & 0,719 & 0,954 & 0,327 \\
\hline
\end{tabular}

WM: whole milk; MPW0: $0 \%$ cheese whey powder $+100 \%$ milk powder; MPW20: $20 \%$ cheese whey powder $+80 \%$ milk powder; MPW40: $40 \%$ cheese whey powder $+60 \%$ milk powder; SEM: standard error of the mean. A: whole milk vs other treatments; B: linear effect of including whey cheese powder; and C: quadratic effect of the inclusion of cheese whey in powdered milk.

As expected, increased consumption over time was seen across all treatments. This agreed with the results found by Lima et al. (2012) and Eckert et al. (2015), who report that feed intake in the first weeks of life is small, since the calf can meet its nutritional requirements with whole milk; increasing solid food consumption increases when animals reach approximately 4 weeks of age. The regression equations that best represented the intake variables were: $\mathrm{Y}=-79.14+114.54 \mathrm{X}\left(\mathrm{R}^{2}=\right.$ 0.93 ) for concentrate intake; $Y=34.68+13.69 X$ $\left(\mathrm{R}^{2}=0.97\right)$ for hay consumption; and $\mathrm{Y}=378.57$ $+128.24 \mathrm{X}\left(\mathrm{R}^{2}=0.94\right)$ for total dry matter intake, where $\mathrm{Y}$ represents the evaluated variable and $\mathrm{X}$ the experimental week.

To facilitate an easier transition of the calf from the pre-ruminant stage to the functional ruminant stage, physical and metabolic development of the digestive tract is critical. It is important to emphasize that the intake of solid food encourages microbial fermentation and the production of short chain fatty acids, which subsequently stimulate rumen development and growth (MIRZAEI et al., 2014). This allows the animals to enjoy the solid diet provided and meets the nutritional needs not met by the limited amount of milk available.

This experiment was designed with the knowledge that solid food intake is of significant importance in animal performance, particularly in the development of gastric compartments. According to Sweeney et al. (2010), solid food intake can facilitate early weaning and lower the stress of calves during the weaning phase. We were able to conclude that associations of up to $40 \%$ of whey did not interfere with food consumption and animal development. The similarity observed between the treatments is particularly interesting as it supports the proposed goal of replacing a higher cost diet, whole milk, with a less expensive one, cheese whey and industrial waste milk.

Lee et al. (2009) state in their performance comparison between dairy-fed and calf-fed dairy calves that their average daily intakes were similar and that calves consumed similar amounts of concentrate, roughage and water at both daily and weekly measurement increments. Both groups presented similar body development across the treatments. Lima et al. (2012) also observed no significant differences in the dry matter intake of calves receiving whey in the liquid diet.

For feed conversion, no significant difference was observed in any of the contrasts $(\mathrm{P}>0.05)$ as a function of the treatments. Feed conversion translates into efficiency, which refers to how much food is ingested per pound of live weight gain. Víegas et al. (2017) evaluated the performance of calves with the inclusion of different levels of replacements as substitutes for whole milk and 
observed a higher feed conversion than the values obtained this study, with an overall average of 2.20 .

No significant effect was observed in the evaluated contrasts concerning the development of calves (Table 3). The animals entered the experimental period with similar weights $(\mathrm{P}>$ 0.05 ), around $35 \mathrm{~kg}$, and during this period the results showed no significant difference $(\mathrm{P}>0.05)$. At the end of the experimental period (at 60 days) the animals had an average weight of $50.28 \mathrm{~kg}$ per calf, which was not influenced by the liquid diets $(\mathrm{P}>0.05)$. Similar results were found by Bharti et al. (2012), which taken together conclude that the use of whole milk or milk replacer did not result in significant differences in animal performance with respect to final live weight. Górka et al. (2011) obtained opposite results where calves fed whole milk gained more weight during the experimental period than those fed commercial substitute treatments. The composition of the substitute tested by Górka et al. (2011) has components of vegetal origin and differs from that of the substitute used in this study. This difference can be used to explain the difference between the results of these two studies.

Table 3. Average daily gain (ADG; $\mathrm{kg}$ ), total weight gain (TWG; kg), withers height (WH; $\mathrm{cm})$, perimeter thoracic $(\mathrm{PT} ; \mathrm{cm})$, body length $(\mathrm{BL} ; \mathrm{cm})$, and croup height $(\mathrm{CH} ; \mathrm{cm})$ of calves receiving milk powder associated with whey powder in liquid diet.

\begin{tabular}{|c|c|c|c|c|c|c|c|c|}
\hline \multirow{2}{*}{ Variables } & \multicolumn{4}{|c|}{ Treatments } & \multirow{2}{*}{ SEM } & \multicolumn{3}{|c|}{$P$ value of contrasts } \\
\hline & WM & MPW0 & MPW20 & MPW40 & & A & B & $\mathrm{C}$ \\
\hline $\mathrm{ADG}$ & 0,443 & 0,319 & 0,312 & 0,343 & 0,03 & 0,181 & 0,835 & 0,831 \\
\hline TWG & 18,63 & 13,43 & 13,11 & 14,42 & 1,52 & 0,181 & 0,834 & 0,830 \\
\hline WH & 86,00 & 86,77 & 85,30 & 88,85 & 1,20 & 0,726 & 0,582 & 0,408 \\
\hline PT & 88,35 & 87,16 & 85,90 & 85,57 & 1,13 & 0,424 & 0,657 & 0,871 \\
\hline $\mathrm{BL}$ & 76,66 & 74,66 & 74,30 & 76,28 & 0,73 & 0,371 & 0,480 & 0,522 \\
\hline $\mathrm{CH}$ & 87,50 & 86,12 & 86,28 & 87,57 & 0,42 & 0,420 & 0,270 & 0,625 \\
\hline
\end{tabular}

WM: whole milk; MPW0: 0\% cheese whey powder $+100 \%$ milk powder; MPW20: $20 \%$ cheese whey powder $+80 \%$ milk powder; MPW40: 40\% cheese whey powder $+60 \%$ milk powder; SEM: standard error of the mean. A: whole milk vs other treatments; B: linear effect of including whey cheese powder; and C: quadratic effect of the inclusion of cheese whey in powdered milk.

The withers and croup height, body length, and thoracic perimeter did not present statistical differences according to treatments; they are parameters that are directly related to the animal's weight and provide a more specific metric to describe individual's development. The withers height averages of the studied treatments were similar to those found by Ballou et al. (2013), who reported a withers height of $86.5 \mathrm{~cm}$ for Holstein calves fed a low nutrient content diet containing surrogate. Hill et al. (2008) tested 4 types of dairy replacers with different compositions and did not observe significant differences in withers height between treatments in Holstein calves. Lima et al.
(2012) also found no significant difference when evaluating calves receiving cheese + colostrum whey up to 60 days of age, and observed lower values when compared with the average observed in this study, in which the withers height averaged $78.76 \mathrm{~cm}$.

The results for thoracic perimeter measurements were superior to those found by Lima et al. (2012) who obtained means of $80.12,76.75$, and $79.40 \mathrm{~cm}$ for the whole milk diets, milk + cheese whey, and colostrum + cheese whey, respectively. Masum et al. (2009) evaluated the development of crossbred calves of weight similar to that of the animals in this study receiving raw milk and soy milk-based 
replacers in the liquid diet. Their calves presented body length measurements around 63.12 and 65.12 $\mathrm{cm}$, respectively, which are lower values than those found for the animals in this study. Their results did not present significant statistical differences for the daily and total increase in the body length of calves.

For croup height, no significant differences $(\mathrm{P}>$ $0.05)$ were observed. The measurements in this study resulted in higher averages than those found by Lima et al. (2012) in their study evaluating the performance of calves receiving cheese whey associated with colostrum until 60 days of age. Although the diets tested were similar, these differences should be attributed to the genetics of the animals used in these experiments, since they were all crossbred animals with no breed pattern set.

For suckling puppies, whole milk is thought of as the most complete food; however, in view of its high cost, we have sought out options that are more economically advantageous and do not damage the physiological development of these animals. The results of this study indicate that our proposed diets succeed in meeting our goal as the diets did not harm the performance of the animals. The animals accepted the diets well and presented similar development, which supports the use of discarded milk powder associated with whey powder in the proportions studied herein. These proportions also represent the best economic configuration.

For cost and revenue indicators and economic outcome measures comparing the proposed liquid diets (LPS0, LPS20, and LPS40) to the control treatment (LI), it was observed that the treatment which replaced whole milk with $100 \%$ milk powder produced an additional profit of $\mathrm{R} \$ 108.48$. The treatments containing $20 \%$ and $40 \%$ whey powder produced additional profits of $\mathrm{R} \$ 116.86$ and $\mathrm{R} \$$ 114.24 respectively (Table 4). This result reflects the lower cost of food under the tested diets; the whole milk treatment was twice as expensive as the treatments containing whey and industrial whey powder. This difference is attributed to the cost of whole milk, which accounts for up to $80 \%$ of the total cost of calf rearing according to Coan (2008).

Table 4. Economic performance indicators of the total replacement of whole milk substitutes for milk powder and cheese whey powder.

\begin{tabular}{lcccc}
\hline \multirow{2}{*}{ Indicators } & \multicolumn{3}{c}{ Treatments } \\
\cline { 2 - 5 } & WM & MPW0 & MPW20 & MPW40 \\
\hline Carcass Yield (\%) & 42,40 & 46,20 & 46,70 & 46,90 \\
Carcass weight (kg/animal) & 22,30 & 22,82 & 22,79 & 22,48 \\
Carcass value (R\$/kg) & 7,00 & 7,00 & 7,00 & 7,00 \\
Food expenditure (R\$/animal) & 233,70 & 128,88 & 120,27 & 120,72 \\
Increase in carcass yield (kg/animal) & - & 0,52 & 0,49 & 0,18 \\
Additional carcass yield value (R\$/animal) & - & 3,66 & 3,43 & 1,26 \\
Additional charge with food (R $\$$ animal) & - & $-104,82$ & $-113,43$ & $-112,98$ \\
Additional Profit (R $\$$ animal) & - & 108,48 & 116,86 & 114,24 \\
\hline
\end{tabular}

WM: whole milk; MPW0: $0 \%$ cheese whey powder $+100 \%$ milk powder; MPW20: $20 \%$ cheese whey powder $+80 \%$ milk powder; MPW40: $40 \%$ cheese whey powder $+60 \%$ milk powder.

The potential additional profit found in the present study was higher than that obtained by Lima et al. (2011). In their study comparing a cheese whey diet associated with whole milk to the standard whole milk diet, an additional profit of R\$ 50.00 was found. This difference can be explained 
by the lower carcass yield in the Lima et al. (2011). Our research demonstrates that replacing $100 \%$ of milk with very low cost byproducts did not harm the performance of the animals and also provided a more economically advantageous production system. The animals receiving whey powder and milk powder presented average carcass weights similar to the animals receiving the control treatment. Morrison et al. (2009) report in their calf replacement diet work that even if the initial cost of the dairy substitute is high, this cost does not influence the total return on investment. The net return can be almost 3 times the cost spent on the initial replacement.

The economic analysis conducted in this study is based on a property with easy access to discarded industrial whole milk powder, which decreases the acquisition costs of this product. These low costs promote its use as a dairy substitute. The results of feeding calves milk powder and cheese whey powder associated with milk powder prove the utility of using the substitute in reducing production costs. The use of whey powder and discarded industrial milk powder, in partial or total substitution to whole milk, is an advantageous option. This is especially true when considering the low purchase price of this byproduct.

\section{Conclusion}

The use of discarded industrial milk powder associated with whey powder in a ratio of up to 80:20 is a viable option for feeding male calves from dairy farms as the mix does not affect the development or consumption of solid food of these animals. Whey provides a significant amount of additional profit for a property with easy access to such products, making it possible to provide a nutritious liquid diet.

\section{Acknowledgment}

Coordination of training for higher level staff (CAPES).

\section{Ethics Committee Approval}

The experiment was conducted according to ethical standards and approved by the Animal Experimentation Ethics Committee of the Federal Rural University of Semiarid (UFERSA), opinion no. 17/2011 / case 23091.002083 / 2011-66 - CEUA / UFERSA.

\section{References}

BALLOU, M. A.; COBB, C. J.; EARLEYWINE, T. J.; OBEIDAT, B. S. Breed and plane of milkreplacer nutrition influence the performance of preand postweaned dairy calves. The Professional Animal Scientist, v. 29, n. 2, p. 116-123, 2013. DOI: 10.15232/ S1080-7446(15)30209-6

BHARTI, P. K.; KAMBOJ, M. L.; TYAGI, A. Comparative effect of feeding commercial milk replacer and whole milk on growth. Indian Journal of Animal Sciences, v. 82, n. 10, p. 1221-1224, 2012.

CARVALHO, F.; PRAZERES, A. R.; RIVAS, J. Cheese whey wastewater: characterization and treatment. Science Total Environment, v. 445-446, p. 385-396, 2013. DOI: 10.1016/j.scitotenv.2012.12.038

COAN, R. M. Sucedâneos na criação de bezerros.2008. Disponível em: http://www.coanconsultoria.com.br/ noticias.asp?id=11. Acesso em: 14 fev. 2019.

ECKERT, E.; BROWN, H. E.; LESLIE, K. E.; DEVRIES, T. J.; STEELE, M. A. Weaning age affects growth, feed intake, gastrointestinal development, and behavior in Holstein calves fed an elevated plane of nutrition during the preweaning stage. Journal of Dairy Science, v. 98, n. 9, p. 6315-6326, 2015. DOI: 10.3168/jds.2014-9062

GAVA, A.; MOLOSSI, F. A.; WICPOLT, N. S.; OGLIARI, D.; CARDOSO, T. C.; TRAVERSO, S. D.; WISSER, C. S. Soro de leite como causa de alta mortalidade de bovinos. Pesquisa Veterinária Brasileira, v. 38, n. 4, p. 620-623. DOI: 10.1590/1678-5150-PVB-5196

GÓRKA，P.; KOWALSKI，Z. M.; PIETRZAK, P.; KOTUNIA, A.; JAGUSIAK, W.; ZABIELSKI, R. Is rumen development in newborn calves affected by different liquid feeds and small intestine development? Journal of Dairy Science, v. 94, n. 3, p. 3002-3013. DOI: 10.3168/jds.2010-3499

HILL, S. R.; KNOWLTON, K. F.; DANIELS, K. M.; JAMES, R. E.; PEARSON, R. E.; CAPUCO, A. V.; AKERS, R. M. Effects of milk replacer composition 
on growth, body composition, and nutrient excretion in preweaned Holstein heifers. Journal of Dairy Science, v. 91, n. 8, p. 3145-3155. DOI: 10.3168/jds.2007-0860

LEE, H. J.; KHAN, M. A.; LEE, W. S.; YANG, S. H.; KIM, S. B.; KI, K. S.; KIM, H. S.; HA, J. K.; CHOI, Y. J. Influence of equalizing the gross composition of milk replacer to that of whole milk on the performance of Holstein calves. Journal Animal Science, v. 87, n. 3, p. 1129-1137. DOI: $10.2527 /$ jas.2008-1110.

LIMA, E. L. C.; MOURA, J. F.; CARDARELLI, H. R. Optimized fermentation of goat cheese whey with Lactococcus lactis for production of antilisterial bacteriocin-like substances. LWT - Food Science and Technology, v. 84, p. 710-716, 2017. DOI: 10.1016/j. lwt.2017.06.040

LIMA, R. N. de; LIMA, P. O.; AROEIRA, L. J. M.; MIRANDA, M. V. F. G.; LOPES, K. T. L.; DIÓGENES, G. V.; PEREIRA, M. I. B.; SOUZA, I. T. do N.; ROSSATO, C. H. Desempenho de bezerros aleitados com soro de queijo em associação ao colostro. Pesquisa Agropecuária Brasileira, v. 47, n. 8, p. 1174-1180, 2012. DOI: $10.1590 / \mathrm{S} 0100-204 X 2012000800019$

LIMA, R. N.; LIMA, P. O; CÂNDIDO, M. J. D.; PONTES, F. S. T.; MOREIRA, R. H. R.; AQUINO, R. M. S. Avaliação econômica de dietas líquidas à base de soro de queijo in natura para bezerros. Revista Brasileira de Saúde e Produção Animal, v. 12, n. 1, p. 14-21, 2011.

MASUM, A.; ISLAM, M.; KHAN, M. Utilization of soymilk as milk replacer for calves. Journal Animal Science, v. 38, n. 1-2, p. 102-107, 2009. DOI: 10.3329/ bjas.v38i1-2.9918

MIRZAEI, M.; KHORVASH, M.; GHORBANI, G. R.; KAZEMI-BONCHENARI, M.; RIASI, A.; NABIPOUR, A.; VAN DEN BORNE, J. J. G. C. Effects of supplementation level and particle size of alfalfa hay on growth characteristics and rumen development in dairy calves. Journal of Animal Physiology and Animal Nutrition, v. 99, n. 3, p. 553-564, 2014. DOI: 10.1111/ jpn.12229
MORRISON, S. J.; WICKS, H. C. F.; FALLON, R. J.; TWIGGE, J.; DAWSON, L. E. R.; WYLIE, A. R. G.; CARSON, A. F. Effects of feeding level and protein content of milk replacer on the performance of dairy herd replacements. Animal, v. 3, n. 11, p. 1570-1579, 2009. DOI: $10.1017 / \mathrm{S} 1751731109990437$

NATIONAL RESEARCH COUNCIL - NRC. Nutrient requirements of dairy cattle. Washington: National Academies Press, 2001. doi: 10.17226/9825

PALMIERI, N.; FORLEO, M. B.; SALIMEI, E. Environmental impacts of a dairy cheese chain including whey feeding: An Italian case study. Journalof Cleaner Production, v. 140, n. 2, p. 881-889, 2017. DOI: 10.1016/j.jclepro.2016.06.185

SILVA, D. J.; QUEIROZ, A. C. Análise de alimentos: métodos químicos e biológicos. Viçosa: Editora UFV, 2009.

SOBERON, F.; RAFFRENATO, E.; EVERETT, R. W.; VAN AMBURGH, M. E. Preweaning milk replacer intake and effects on long-term productivity of dairy calves. Journal of Dairy Science, v. 95, n. 2, p. 783-793, 2012. DOI: $10.3168 /$ jds.2011-439111

SWEENEY, B. C.; RUSHEN, J.; WEARY, D. M.; PASSILÉ, A. M. Duration of weaning, starter intake and weight gain of dairy calves fed large amounts of milk. Journal of Dairy Science, v. 93, n. 1, p. 148-152, 2010. DOI: $10.3168 /$ jds.2009-2427

VÍEGAS, J.; SKONIESKI, F. R.; WEBER, A.; PINTONETO, A.; OLIVEIRA, R. L.; RIBEIRO, C. V. M.; BERMUDES, R. F.; NÖRNBERG, M. F. L. Soro de leite em substituição ao leite na cria de bezerros. Arquivos de Ciências Veterinária e Zoologia UNIPAR, v. 20, n. 1, p. 9-13, 2017. DOI: 10.25110/arqvet.v20i1.2017.6313

YADAV, J. S. S.; YAN, S.; PILLI, S.; KUMAR, L.; TYAGI, R. D.; SURAMPALLI, R. Y. Cheese whey: a potential resource to transform into bioprotein, functional/nutritional proteins and bioactive peptides. Biotechnology Advances, v. 33. n. 1, p. 756-774, 2015. DOI: $10.1016 /$ j.biotechadv.2015.07.002 
